\title{
Effect of Land-farming Oily Sludge on Run-off Water
}

\author{
Hasan Mahdi Mohammed Al-Khateeb
}

\begin{abstract}
Oily sludge produced as by product from oil industry represent a potential source of environmental pollution. Land-farming is one of the least expensive and easiest methods to dispose of oily sludge. However, Run-off water of oily waste land farms may represent potential pollution source and require control concern. The purpose of this paper is to investigate surface run-off water pollution that is caused by land-farming an oily sludge produced by Daura Refinery in Iraq. A homogenous loamy sand soil was divided into 24 plots of one square meter and mixed with the sludge for the upper $15 \mathrm{~cm}$ layer according to different ratios and intervals. The ratios were three by weight as $(1: 3),(1: 6)$, and $(1: 10)$ as sludge fresh weight: soil dry weight. The intervals were weekly, monthly, and seasonally. Some plots subjected to tillage for the upper $15 \mathrm{~cm}$ weekly. Raw water drawn from the Tigris River was used to irrigate the plots with (40 liters) by two-day intervals throughout the experiments of this study. Water samples were collected from plots surface run-off water and tested for Oil \& Grease O\&G, Chemical Oxygen Demand COD, pH and some heavy metals. The results showed that the monthly sludge application according to (1:10) (fresh sludge wt: dry soil wt.) was the best application rate among the others regarding run-off water quality. No considerable run-off water (drainage) pollution by oils (3-12ppm) and/or heavy metals contained in the applied sludge. No detectable adverse effect of soil tillage on run-off quality for the monthly (1:10) treatment.
\end{abstract}

Index Terms - land-farming, run-off, oily sludge, Oil and Grease.

\section{INTRODUCTION}

Oily sludge produced as by product from oil industry represent a potential source of environmental pollution [1]. One of the important sources of the sludge produced by wastewater treatment plants of refineries. Ultimate disposal of oily sludge has been a problem for decades, and due to pressure imposed by environmental agencies, disposal alternatives has been reduced and optimized. The ultimate disposal may be done by many ways, such as deep-well injection, land-farming, ocean disposal, incineration [2]. Land-farming is one of the least expensive and easiest methods of disposal [3]. But, concern should be kept about sludge biodegradation through providing sufficient Oxygen to soil where micro-organism degreed the sludge. In addition, there is continued potential for leaching oil and soluble metals from the site [4]. Land-farming is also called as land treatment, land application, land spreading, sludge farming, and soil cultivation. Sometime, it has been referred to as land disposal [5], [6]. It has been practiced since the eighties of the last century in most of refineries of USA, United Kingdom, the Netherlands, Sweden, Denmark, France, New Zealand,

Hasan Mahdi Mohammed Al-Khateeb, University of Kufa Civil Eng. Dept., Faculty of Engineering, Najaf, Iraq and Brazil [6], [7] and [8]. Some of Arab-oil producing countries adopted this method since the 1990s to dispose of oily sludge [9]. One of motivates to adopt this method is that improving soil fertility and structure [10]. Although microbial assimilation is the principal means of waste degradation in land-farming, the contribution of other non-biological processes (chemical and photochemical processes, evaporation, and volatilization) are also significant [7]. However, Run-off water of oily waste land farms may carry considerable amounts of pollutants, especially when higher rate of liquid oily waste application is followed in land-farming using a coarse-textured soil of high moisture content and low adsorption capacity. In practice, many refineries recycle the land farm run-off back to wastewater-treatment system for cleanup [11].

The purpose of this paper is to investigate surface run-off water pollution that is caused by land-farming the oily sludge.

\section{MATERIALS AND METHODS}

\section{A. Materials}

A homogenous loamy sand soil was collected from top soil of a selected site inside Daura Refinery and leveled with a thickness of $50 \mathrm{~cm}$ over an area of $(6.5 \mathrm{~m} \mathrm{x} 10 \mathrm{~m})$ inside the refinery. The land was divided into 24 plots of one square meter each distributed at one meter clear spacing, and each of them surrounded by $10 \mathrm{~cm}$ height bricks to be isolated from the others. Table (1) show some physical and chemical properties of the soil. Soil particle size distribution was determined by the hydrometer method after sieving [12], soil bulk density by Core method, electrical conductivity (EC) was measured in (1:2) water extract while $\mathrm{pH}$ was measured in (1:2.5), [13]. Fig. (1) shows a sketch for a typical plot.

TABLE (1) DETERMINED CHARACTERISTICS OF THE SOIL USED.

\begin{tabular}{|c|c|}
\hline Characteristic & Results \\
\hline Sand & $84.6 \%$ \\
\hline Silt & $4.5 \%$ \\
\hline Clay & $10.8 \%$ \\
\hline Soil texture & loamy sand \\
\hline Bulk density & $1.35 \mathrm{~g} / \mathrm{cm} 3$ \\
\hline $\mathrm{pH}$ & 7.41 \\
\hline Electric conductivity (ECe) at $25^{\circ} \mathrm{C}$ & 1.56, \\
\hline Total nitrogen & $\mathrm{mS} / \mathrm{cm}$ \\
\hline
\end{tabular}

Raw water drawn from the Tigris River was used to irrigate the plots with (40 liters) by two-day intervals throughout the experiments of this study. This irrigation was found (by field trail runs) to keep soil moisture above $10 \%$. Water used in irrigation had approximately constant physical and chemical characteristics. Table (2) lists raw water characteristics used. 


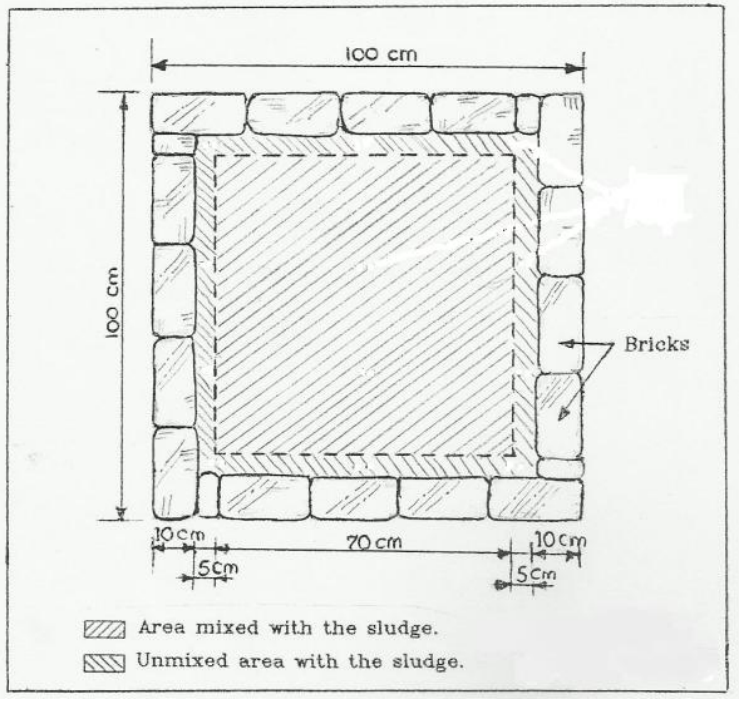

FIGURE (1) TOP VIEW SKETCH FOR A TYPICAL PLOT ADOPTED.

TABLE (2) RAW WATER CHARACTERISTICS USED IN IRRIGATION.

\begin{tabular}{|c|c|}
\hline Parameter & Range \\
\hline $\mathrm{pH}$ & $7.6-7.8$ \\
\hline Alkalinity as $\mathrm{CaCo}_{3}, \mathrm{ppm}$ & $148-190$ \\
\hline Total Dissolver $\mathrm{Solids}_{\mathrm{ppm}}$ & $435-690$ \\
\hline Total hardness as $\mathrm{CaCo}_{3}, \mathrm{ppm}$ & $330-448$ \\
\hline Chloride, ppm & $136-212$ \\
\hline
\end{tabular}

Sludge used in the experiments of this study was drawn from Sludge Thickening Tank of Wastewater Treatment plant of Daura Refinery. The plant consists of two stages of API separator (floatation), coagulation, dissolved air floatation (DAF), aeration, sedimentation and disinfection. The sludge was collected from different stages of the Wastewater Treatment Unit to be thickened in this tank. It was the end sludge product of the plant. The sludge was slightly variable in quantity and quality due to influent variation of the unit. The influent was collected from different refinery activities like washing and cleaning of refinery tanks, equipment, and apparatus ; cooling towers ; oil spills ; laboratories drain; and so on.

Table (3) lists sludge characteristics ranges corresponding to periodical analysis. Sludge density was determined by Hydrometer method according to the standard test method (ASTM, Designation: D 1298-85), and ash content by the standard test method (ASTM, Designation: D 1298-87), both methods are mentioned by ASTM, 1988 [14]. Electrical conductivity and $\mathrm{pH}$ were measured for the sludge without dilution. Total nitrogen was determined by Kjeldahl digestion method [15]. Heavy metals (total content) were measured by standard test method (301A) of Atomic Absorption Spectrophotometry after digestion with $\mathrm{HNO}_{3}$ and $\mathrm{HCIO}_{4}$. Phenol by standard method $(510 \mathrm{~B})$ of chloroform extraction after pretreatments of filtration; treatment with $\mathrm{H}_{3} \mathrm{PO}_{4}$, $\mathrm{CuSO}_{4}$, and $\mathrm{FeSO}_{4}$; and distillation [16]. Water, oil, and sediment (residue) were determined using a simple development of the standard test method (ASTM Designation: D473-87).

The sludge was characterized by alkaline $\mathrm{pH}(8-8.5)$, high water content $(84.7-86.2 \%)$, low oil content (4.7-5.3\%), very low phenol content (0.026-0.029 ppm), and low overall heavy metal content.

TABLE (3): CHARACTERISTICS OF THE END SLUDGE PRODUCT OF DAURA REFINERY WASTEWATER TREATMENT PLANT USED IN THE STUDY.

\begin{tabular}{|c|c|c|}
\hline Characteristic & Range & Unit \\
\hline Density at $35^{\circ} \mathrm{C}$ & $1.0004-1.015$ & $\mathrm{~g} / \mathrm{cm} 3$ \\
Electrical conductivity at $25^{\circ} \mathrm{C}$ & $2.75-3.66$ & $\mathrm{mS} / \mathrm{cm}$ \\
$\mathrm{pH}$ & $8.0-8.5$ & \\
Water & $84.5-86.2$ & $\%$ \\
Oil & $4.7-5.3$ & $\%$ \\
Residue & $8.4-9.25$ & $\%$ \\
Ash & $3.15-3.6$ & $\%$ \\
Total Nitrogen & $0.10-0.14$ & $\%$ \\
Phenol & $0.026-0.29$ & $\mathrm{ppm}$ \\
Cadmium & $1.3-1.9$ & $\mathrm{ppm}$ \\
Chromium & $3.9-27.4$ & $\mathrm{ppm}$ \\
Copper & $5.2-37.6$ & $\mathrm{ppm}$ \\
Nickel & $7.6-41.8$ & $\mathrm{ppm}$ \\
Lead & $6.1-7.6$ & $\mathrm{ppm}$ \\
Zinc & $107.5-183.5$ & $\mathrm{ppm}$ \\
\hline
\end{tabular}

\section{B. Methods}

Sludge application to the experimental plots continued during four months. The application was through mixing the sludge with upper $15 \mathrm{~cm}$ soil layer according to different ratios and intervals. The ratios were three by weight as (1:3), (1:6), and (1:10) as sludge fresh weight: soil dry weight. The intervals were weekly, monthly, and seasonally. So, to cover the three rates and the three intervals, nine plots where used. Another variable was tested, that was tillage of the upper 15 $\mathrm{cm}$ soil which mixed with the sludge. To do so, other nine corresponding plots having similar sludge application ratios and intervals were subjected to weekly tillage. Hence, eighteen plots were used for the three independent factors (application ratio, application intervals, and tillage), in addition to six control plots. The sludge quantitated by a balance, applied by buckets, and mixed with the soil using manual shovel, Figures (2) and (3). The weekly soil tillage was, also, made by manual shovel.

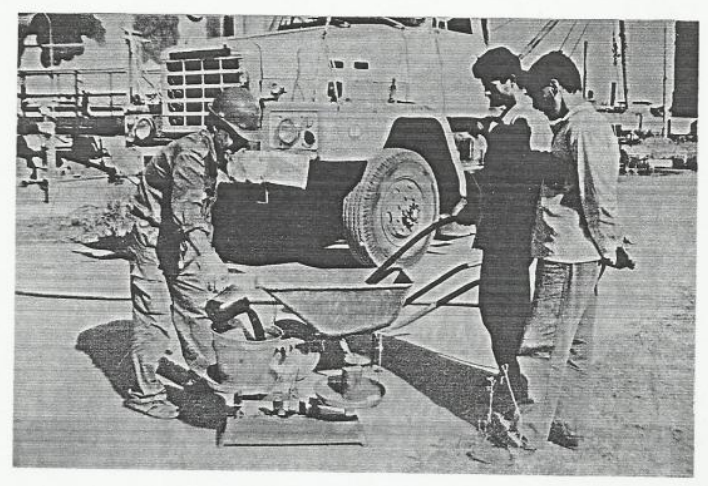

FIGURE (2) SLUDGE QUANTIFICATION.

During the periodical irrigation (every two days), water samples were collected from plots surface run-off water Figure (4). Water sampling was carried out according to different sequence. Sampling was once a week for the plots of weekly sludge application, twice a month for the plots of monthly sludge application, whereas once a month for the plots of seasonal application. 


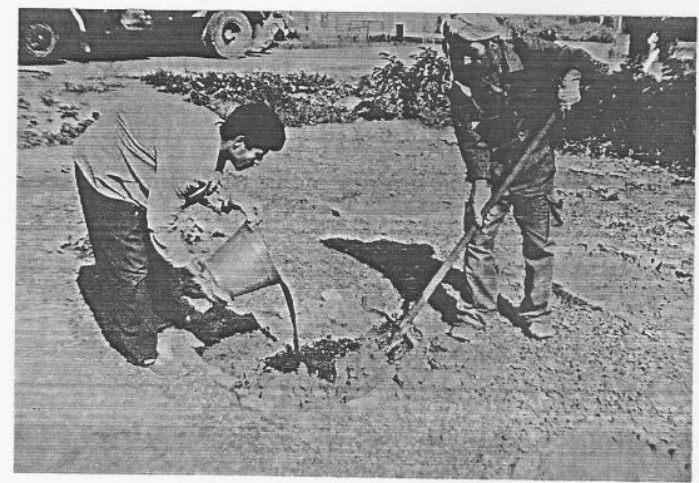

FIGURE (3) SLUDGE APPLICATION.

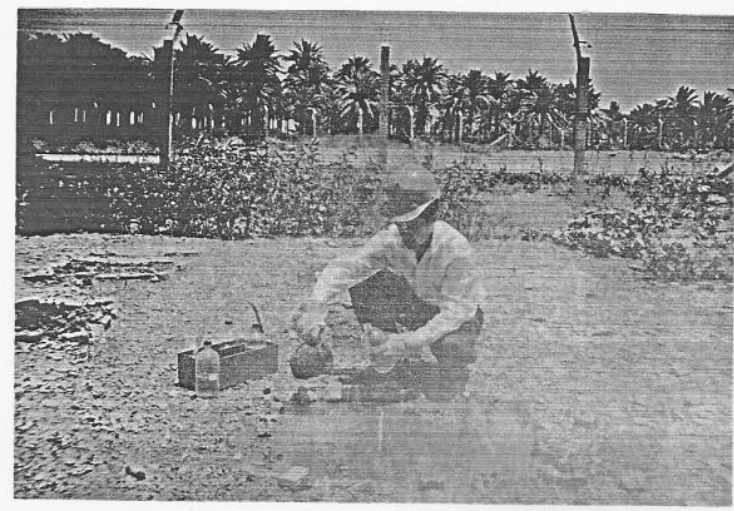

FIGURE (4) SURFACE WATER SAMPLING.

It is worth mentioning that no irrigation was carried out in days of sludge application to avoid over saturating the soil (anaerobic soil conditions). Water samples were collected from control plots at times coincident with water sampling of all other plots to be control water samples. Each of the water samples was analyzed for oil and grease (O\&G), Chemical Oxygen Demand (COD), $\mathrm{pH}$ and some heavy metals.

As oil was the major constituent of the applied sludge, thus it represented a major potential pollutant for the run-off water. The term $(\mathrm{O} \& \mathrm{G})$ represented all oily matter found in the water. $\mathrm{O} \& \mathrm{G}$ was measured by extraction with $\mathrm{CCl}_{4}$ according to the standard (502A) partition -Gravimetric method [16].

COD was measured to be as an indicator of all oxidizable matter as pollutant in the run-off water. COD covers the majority of organic compounds as well as oxidizable mineral salts. COD was measured according to the standard (508) classical reflux method of hot oxidation by potassium dichromate. The $\mathrm{pH}$ was measured to predict solubility of the heavy metals contained by the applied sludge. $\mathrm{pH}$ was measured according to the standard test method (424) using $\mathrm{pH}$-meter [16].

At the end of the experiment (end of the four method), water samples were analyzed for some heavy metals that were found in the applied sludge such as $\mathrm{Cd}, \mathrm{Cr}, \mathrm{Cu}, \mathrm{Ni}, \mathrm{Pb}$, and $\mathrm{Zn}$. Total content determination of the heavy metals was carried out according to the standard test method (301 A) atomic absorption Spectrophotometry after treating with $\mathrm{HNO}_{3}[16]$.

\section{RESULTS AND DISCUSSION}

In this study, many factors affecting surface run-off water pollution caused by sludge land-farming were fixed such as soil factors, sludge characteristics, climate conditions, quality and quantity of irrigation water used.

The soil factors are texture, moisture, adsorption capacity and mixing depth. They were fixed by mixing the sludge with one type of soil to a constant $(0-15 \mathrm{~cm})$ depth. The climate conditions were the same for all experiments curried out at the same place and time. Irrigation water was the same, too, with approximately same quality, Table (2), so as the sludge used, Table (3). The three independent factors (application ratio, application intervals, and tillage) are investigated and discussed here according to two main parameters O\&G and COD. Heavy metals and $\mathrm{pH}$, also, checked.

\section{A. $O \& G$ content}

The three figures (5), (6) and (7) illustrate $O \& G$ concentration in surface run-off water samples of the plots treated by various sludge application ratios at weekly, monthly and seasonally intervals, respectively. Scrutiny of the three figures shows, generally, that $O \& G$ in the run-off water increases as sludge application ratio increases. In addition, curves of the two treatment (1:6) and (1:10) are close to each other in comparison to that of the $(1: 3)$ treatment. This may be attributed to the fact that soil tends to adsorb the applied sludge (including its oily constituents). But, when an enough quantity of the sludge was applied to reach a certain level that exceeded soil adsorption capacity, free lumps of the excess sludge might form in the soil due to the formation of nonhomogeneous soil/sludge mixture. These lumps were subjected to rather low soil forces due to soil structure weakness caused by heavy sludge application. Sludge lumps therefore were easily removed from the soil and dispersed in the surface run-off water causing higher concentrations of O\&G in the run-off water. Thus, when sludge application ratio increased, probability and extent of free sludge lumps present in the soil was also increased, leading to increase in $O \& G$ in the run-off water.

The effect of sludge application intervals interfered with other affecting factors. These factors could be classified into two groups according to the effect of increasing or decreasing $O \& G$ and the run-off water. The first group includes some factors that reduce $O \& G$ such as soil surface washing by the run-off water, evaporation of water and oil from the treated soil, and oil degradation in the soil. In contrast, the other group that increasing $O \& G$ is represented by sludge accumulation (especially, its oily content) in the soil due to the successive sludge applications. Oil degradation can be considered the slowest factor affecting oil reduction in the treated soil and the run-off water when compared with factors of evaporation, wash out and leachate [10].

The most affective factor that controls O\&G in the soil and the run-off water is sludge accumulation in the soil resulting from the successive sludge applications. Minimizing sludge application intervals increases sludge quantity mixed with the soil. For example according to the (1:3) application ratio, (33 $\mathrm{kg}$ ) of the oily sludge were applied in each time of sludge application. Therefore, during the four months of this experiment, total sludge quantities applied to the plots according to the (1:3) application ratio were (462 kg) for (14) weekly applications, (132 kg) for (4) monthly applications, 
and just (33 kg) for a (1) seasonal application. Approximately $5 \%$ of the used sludge was oil, Table (3). Thus $(23 \mathrm{~kg})$ is estimated O\&G added for the (14) weekly applications, $(6.6 \mathrm{~kg}$ ) for the (4) monthly applications, and just (1.65 kg) for the seasonal application. As it illustrated by this example, different oil quantities were accumulated in the plots according to the different application intervals, resulting in variable $O \& G$ concentration in the run-off water.

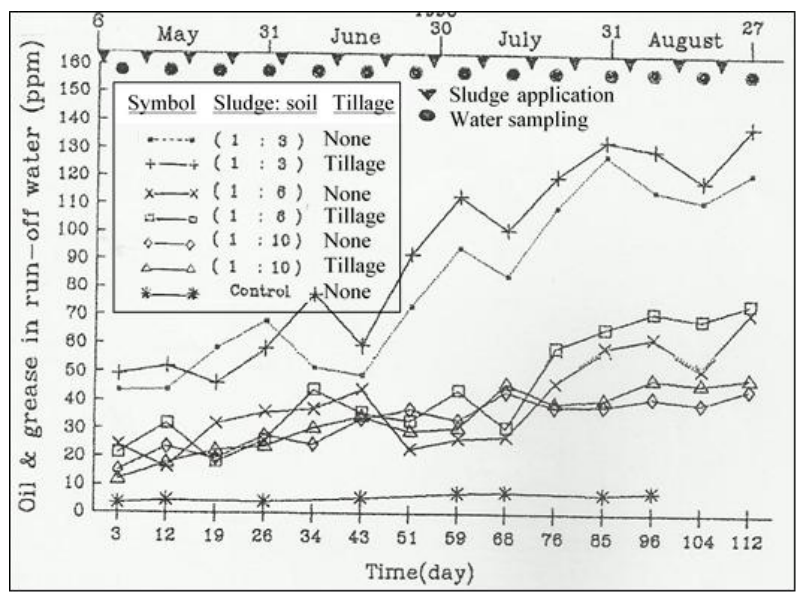

FIGURE (5) OIL \& GREASE IN WATER SAMPLES OF WEEKLY TREATMENT.

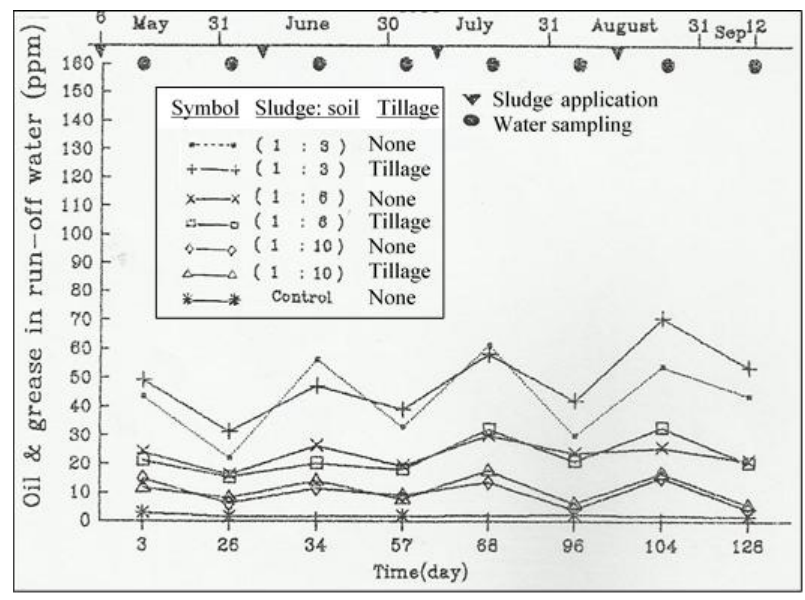

FIGURE (6) OIL \& GREASE IN WATER SAMPLES OF MONTHLY TREATMENT.

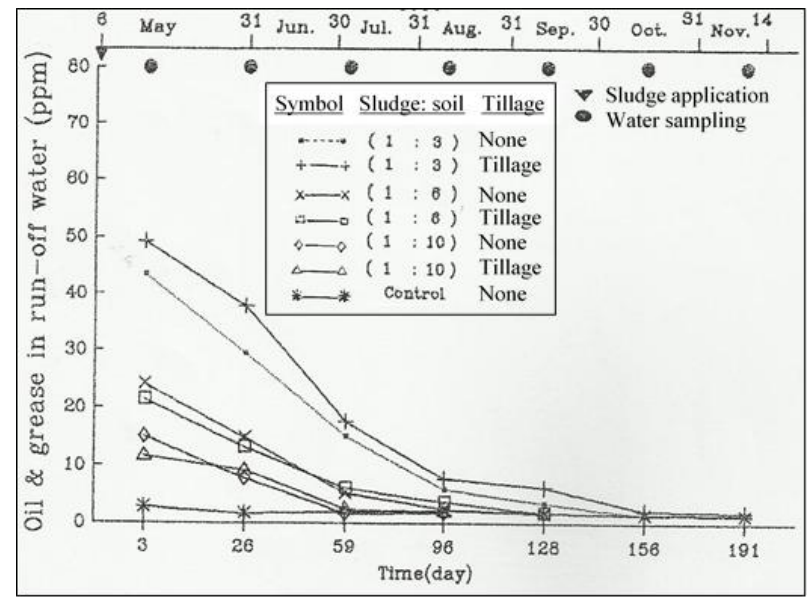

FIGURE (7) OIL \& GREASE IN WATER SAMPLES OF SEASONAL TREATMENT.

In the course of time, when the effect of sludge accumulation exceeds the total effects of the three factors (degradation, evaporation, and soil surface washing), O\&G increase in the run-off water. This is clear in all weekly treatments, especially the $(1: 3)$ treatment which had the rate of sludge accumulation due to its high sludge application ratio. When the effect of sludge accumulation approach the total effect of the three factors (evaporation, degradation, soil surface washing, and sludge accumulation), O\&G are in a rather constant range in the run-off water. This may happened during the monthly treatments, especially, the (1:10) treatment which had the lowest rate of sludge accumulation due to its low sludge application ratio.

Soil weekly tillage caused O\&G to increase generally in run - off water with higher effect in heavier application rates of higher application ratios and shorter intervals. This due to tillage working effect in opposite to the wash out and evaporation factors.

\section{B. COD content}

Figures (8), (9), and (10) illustrate COD content of the run-off water samples of the plots that were weekly, monthly, and seasonally treated with the oily sludge, respectively. These three figures when compared with the three figures (5), (6) and (7), respectively, it can distinguished that high similarity in forms between the COD curves and those of O\&G for the same treatment (same plot). COD variation follow $O \& G$ variation, it increases as $O \& G$ increase with increasing sludge application ratio, decreasing sludge application intervals, and weekly tillage, and vice versa. This indicated that $O \& G$ are the major pollutants found in the run-off water. Therefore, the same factors that affected $O \& G$ in the run-off water may influence the COD.

\section{C. $p H$}

An overall neutral to slightly alkaline, $\mathrm{pH}$ range (7.61-7.81) was observed for the run-off water of all the treated plots. $\mathrm{pH}$ variation of the treated plots' run-off water followed $\mathrm{pH}$ variation of the control plot's run-off water by a range of (7.61-7.74). Both followed $\mathrm{pH}$ variation of the irrigation water.

At intensive sludge application rates, some parts of the excessively applied sludge might spread in the run-off water causing an increase in its $\mathrm{pH}$ due to the alkaline $\mathrm{pH}$ (8-8.5) of the applied sludge. This case may happened after eight times of sludge application according to weekly (1:3) treatment. But, at lighter sludge application rates, no or little parts of the applied sludge may spread in the run-off water causing no or low effect on its $\mathrm{pH}$ that was almost no detectable.

\section{Heavy metals}

Table (4) lists the measured heavy metals' concentrations in the run-off water of the plots treated by the weekly $(1: 3)$ and monthly (1:10) treatments and the control plot. Iraqi limitations for heavy metals' concentrations in waters being drained to streams [17] are also listed.

Results of comparison of treated plots with that of the control plot show that, there is no significant effect of soil mixing with the oily sludge according to the monthly (1:10) treatments in comparison to weekly $(1: 3)$ treatments. 


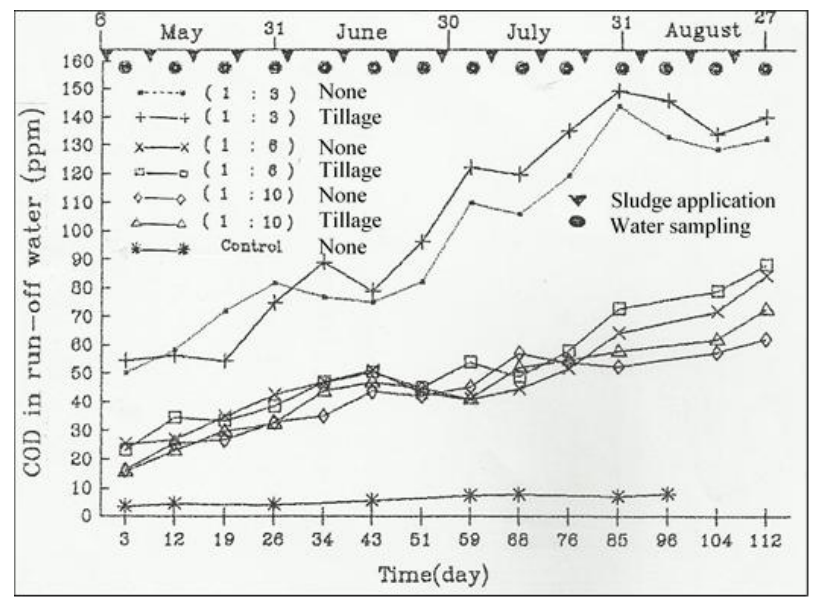

FIGURE (8) COD IN WATER SAMPLES OF WEEKLY TREATMENT.

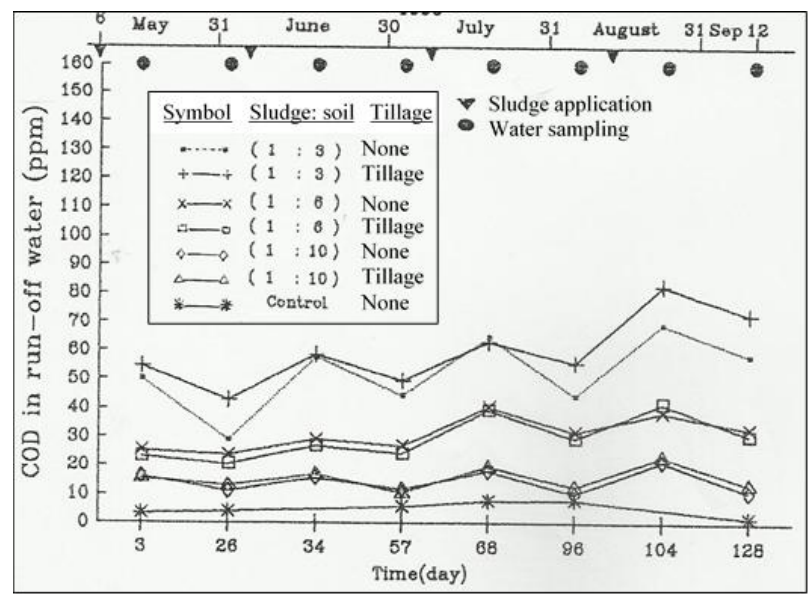

FIGURE (9) COD IN WATER SAMPLES OF MONTHLY TREATMENT

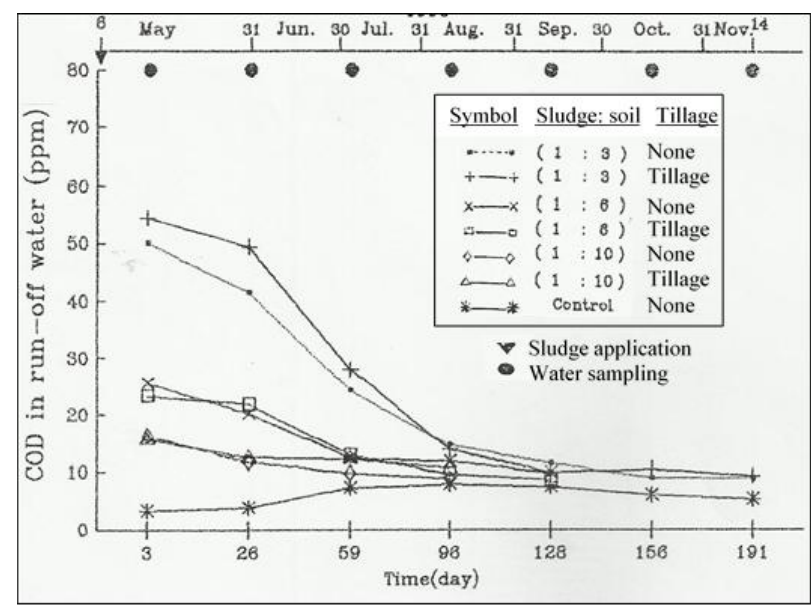

FIGURE (10) COD IN WATER SAMPLES OF SEASONALLY TREATMENT.

It is known that, heavy metals solubility increases in acidic water. But the run-off water $\mathrm{pH}$ of all treated plots was neutral to slightly alkaline. Accordingly, solubility was not the reason for increased heavy metals concentrations in the run-off water. A bearable reason for increasing metals concentrations in the run-off water of the weekly treated plot was the spreading of some parts of the excessively applied sludge in the run-off water. Considering the Iraqi limits for waters being streams listed in Table (4), it can be seen clearly that run-off water of the plot treated by the weekly (1:3) treatment held the heavy metals in concentrations exceeding the limitations, while the run-off water of the plot treated by the monthly $(1: 10)$ treatments was far below the limitations. Accordingly, the last run-off water could be drained to streams regarding heavy metals concentrations, whereas the other cannot.

TABLE (4) HEAVY METALS IN WATER SAMPLES

\begin{tabular}{|c|c|c|c|c|}
\hline (Sludge: soil) appl. ratio & $(1: 3)$ & $(1: 10)$ & control & \multirow{2}{*}{$\begin{array}{l}\text { raqi limitations for } \\
\text { waters being } \\
\text { drained to stream } \\
\text { waters[17] }\end{array}$} \\
\hline $\begin{array}{l}\text { Sludge application } \\
\text { intervals }\end{array}$ & weekly & monthly & none & \\
\hline Heavy metal & \multicolumn{4}{|c|}{ concentration (ppm) } \\
\hline Cadmium (Cd) & 0.26 & 0.005 & 0.005 & 0.01 \\
\hline Chromium (Cr) & 0.181 & 0.051 & 0.045 & 0.10 \\
\hline Copper $(\mathrm{Cu})$ & 0.914 & 0.021 & 0.020 & 0.20 \\
\hline Nickel (Ni) & 0.218 & 0.072 & 0.076 & 0.20 \\
\hline Lead $(\mathrm{Pb})$ & 0.205 & 0.026 & 0.022 & 0.10 \\
\hline Zinc (Zn) & 3.715 & 0.087 & 0.082 & 2.00 \\
\hline
\end{tabular}

\section{CONCLUSION}

Based on the results obtained by this study of land-farming the sludge produced by Daura Refinery wastewater treatment plant using a loamy sand soil, the monthly sludge application according to (1:10) (fresh sludge wt: dry soil wt.) was the best application rate among the others regarding run-off water quality. No considerable run-off water (drainage) pollution by oils (3-12ppm) and/or heavy metals contained in the applied sludge. No detectable adverse effect of soil tillage on run-off quality for the monthly $(1: 10)$ treatment.

\section{ACKNOWLEDGMENT}

The Directorate of Studies, Planning and Follow-up of Iraqi Ministry of Oil supported this work. The Directorate allowed the investigation to be carried out in Daura Refinery and facilitated the work by providing different facilitates, like laboratories, related information, workers, equipment, and financial support.

\section{REFERENCES}

[1] Johnson O. A. and Affam A. C.," Petroleum sludge treatment and disposal: A review", Environ. Eng. Res. 2019; 24(2): 191-201

[2] Vesilind, P.A. "Treatment and disposal of wastewater sludges", Ann Arbor Science publisher, Inc. Michigan, USA. 1979, Pp. 246-248.

[3] Robertson SJ, McGill WB, Massicotte HB, Rutherford PM. "Petroleum hydrocarbon contamination in boreal forest soils: A mycorrhizal ecosystems perspective". Biol Rev. 2007;82:213-240

[4] Grove, G.W. "Use landfarming for oily waste disposal". Hydrocarbon Processing, 1978, 57: 138-140.

[5] Raymond. C.L.; ASCE, M.; and Overcash, M.R. "Land Treatment of Wastes: Concepts and general design", J. Environ. Engineering, 1985 111(2): 141-160.

[6] Handdelston, R.L. "Solid waste disposal: Landfarming", Chemical Engineering, 1979, 86(5): 119-124.

[7] Arora, H.S.; Cantor, R.R.; and Nemeth, J.C. "Land treatment: Available and successful method petroleum industry wastes", Environ International., 1982, 7: 285-291.

[8] Raymond, C.L.; John, R.R.; and Rucker, J.E. " Land Treatment is viable technology for reducing petroleum - waste toxicity and migration potential", Oil \& Gas J., 1987, 85(44): 40-43.

[9] El-Nawawy, A.S. "Landfarming of oily sludge: an overview". Industrial Cooperation In The Arabian Gulf, 1990, (40): 29-46.

[10] AL-Khateeb H.M.," Effect of Oily Sludge Land Treatment on Soil Conditions", EJERS, 2018, 3 (9):1-5.

[11] Knowlton, H.E. and Rucker, J.E. "Lanfarming shows promise for refinery waste disposal". Oil \& Gas J., 1979, 77(20): 108-116. 
[12] Black, C.A., "Methods of Soil Analysis, Part 1", American Soc. Of Agronomy, Inc., Madison, Wisconsin, USA, 1965.

[13] United States Salinity Laboratory Staff, "Diagnosis and improvement of saline and alkali soils", Handbook 60. U.S. Govt. Printing Office, Washington, DC., USA, 1954.

[14] ASTM "Annual book of ASTM standards; Petroleum products, Lubricants, and Fossil Fuels." Sec. (5), Vol. (05-01), American Society for Testing and Materials, Easton, MD, USA. 1988.

[15] Black, C.A., ed. "Methods of Soil Analysis, Part 1", American Soc. of Agronomy, Inc., Madison, Wisconsin, USA, 1965.

[16] APHA-AWWA-WPCF., "Standard Method of Examination of Water and wastewater". 14th edition, American Public Health Association, Washington, DC., USA, 1975.

[17] Directorate of Environmental Engineering "New Measures for Rivers Conservation Regulations from Pollution: Regulation of Rivers Conservation, no. 25, 1976", Ministry of health, Baghdad, Iraq, 1976. (Written by Arabic).

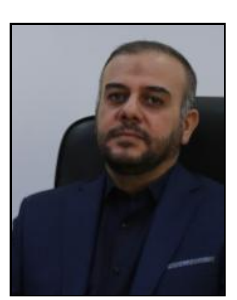

Assist. Prof. Dr. Hasan Mahdi M. Alkhateeb

Born in Najaf Ashraf-Iraq in 1971 and awarded B.Sc. in civil engineering in 1994 from College of Engineering, University of Mustansiriya in Baghdad, Iraq. The same University awarded Alkhateeb the M.Sc. in environmental engineering in 1997 and Ph.D. in Environmental Engineering in 2002.

He designed a lot of water supply and sewerage projects for Iraqi cities including sewerage networks, pump stations and treatment plants. He prepared so many environmental assessment studies for a verity of industrial and services projects. He is now a faculty member at the Civil Engineering Department, Faculty of Engineering- University of Kufa, Iraq. He is the acting dean of the Faculty of Engineering in University of Kufa. His published research articles were in the fields of water resources, hydraulic structures and environmental engineering like preliminary and biological wastewater treatment, performance and hydraulics of pump stations, groynes and other hydraulic structurs.

Assist. Prof. Dr. Hasan Alkhateeb is consultant member of Environment Protection and Improvement Council in Najaf Ashraf Province, Iraq since 2004. He is a member of the scientific committee of the Civil Engineering Dep, University of Kufa. 